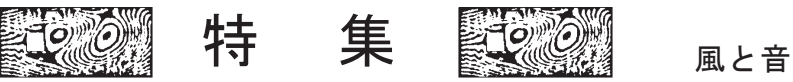

\section{風が建物屋内での音響計測にあたえる影響について Influence of Wind Noise on the Acoustic Measurement in the Room}

\author{
丸山勇祐 ${ }^{* 1}$ \\ 藤橋克己 ${ }^{* 1}$ \\ 島村亜紀子*2 \\ Yusuke MARUYAMA, Katsumi FUJIHASHI, Akiko SHIMAMURA
}

\section{1.はじめに}

高架橋, 風力発電施設, ダムの放水といったものから 発生する低周波音の問題が取り上げられるようになって きているが，低周波音の測定結果について明確に報告さ れている例は少ない。その要因のひとつとして低周波領 域の音圧と風の中に含まれる乱れ成分に伴う圧力変動の 区別ができないことが上げられる。一方，低周波音（特 に $20 \mathrm{~Hz}$ 以下の超低周波音）の被害は長期暴露によって 生じるといわれており，屋内においても生じるといわれ ている。屋外を吹く風は一般に乱れを含んでいるため, 建物外壁に風が当たると乱れに応じた壁面圧力の変動が 生じ，それが直接壁を伝わって室内に入り込むことが考 えられる。よって, 屋内において低周波音を含む音響計 測を行う場合においても，風の影響を考慮する必要があ るといえる。室内における音響計測においては，耳に聞 こえるレベルで無ければ屋外の風の影響について注意を 払われることがほとんどないが，外の風の変動とともに 騒音計の音圧レベル（特に低周波音領域）が変動するこ とが指摘 1)されており，特に低周波領域においては重大 な影響を与える可能性があるといえる。これらのことか ら建物屋内における音響計測への風の影響を明確にする 必要があると考えられる。筆者らは，比較的風の強い地 域に建つ一般的な 2 階建ての建物の居室において低周波
音レベル計と精密騒音計による暗騷音（耳に聞こえる音 が無く風の影響を含むもの）の計測を長期間実施した。 計測結果に基づいて，室内の音響計測における風の影響 について検討した結果を報告する。

\section{2. 計測概要}

計測を行った建物周辺の状況を図 1 に示す。日本海に 面寸る平野部にあり, 海岸線からおよそ $1.5 \mathrm{~km}$ 程度の 2 階建ての建物の 2 階の 1 室において計測を行った。建物 が建っている場所は，比較的大きな建物が少ない集落の 端で，北側及び東側には農地が広がっており，西側には 数件の建物が散在している。写真 1 に計測を行った建物 を北東側から撮影したものを示す。計測室は，2 階の北 向きの部屋で行い，計測中は常時，空・ドアを閉めた状 態とした。計測はこの部屋に置かれた，低周波音レベル 計 (NA-18A : リオン) 及び精密騒音計 (NA-28: リオン) にて行った。騒音計の設置状況を写真 2 に示す。サンプ リングは騒音計の Leq 出力を 1 秒毎に保存した。風の計 測については建物脇に立てたポールで地上 $10 \mathrm{~m}$ の高さで 行った。10 分毎に, 平均風速・風向と風速の標準偏差を 保存した。農村であるため, 周辺での暗騒音の発生がほ とんどない夜 22 時〜朝 5 時の計測データを対象とし, 欠 落データを除いて 3 ケ月〜半年の長期計測を実施した。

\footnotetext{
* 1 前田建設工業（株）技術研究所

Technical Research Institute, Maeda Corporation

* 2 前田建設工業（株）東北支店

Tohoku Office, Maeda Corporation
} 


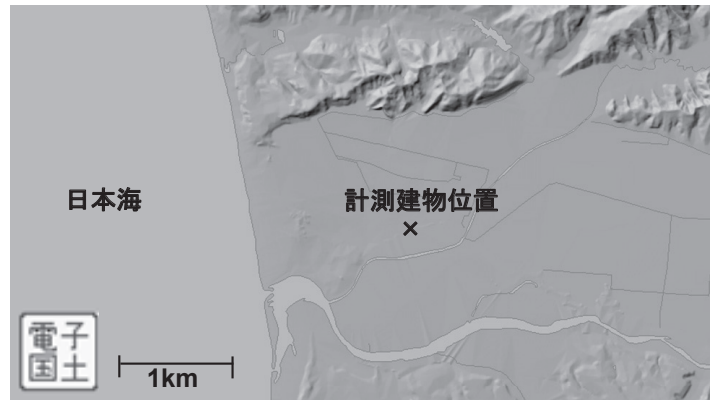

図 1 計測建物周辺の状況

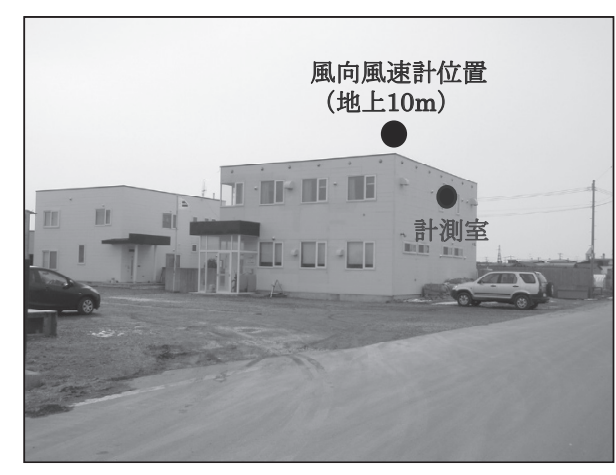

写真 1 計測建物

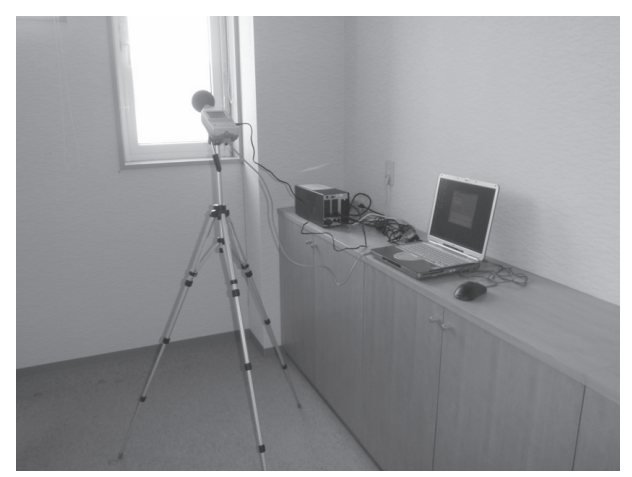

写真 2 計測状況

3. 計測結果

3. 1 計測地点の風の状況

図 2 亿騒音計測時の風配図, 図 3 亿風向別平均風速を 示す。南西寄りと東北東寄りの風の頻度が高くなってい る。平均風速は南西寄りの風が高くなっており, 西南西 の風が一番強い。図 4 に 10 分間平均風速之風速の標準偏 差の関係を示寸。風速が低い時にはデータがばらつくた め, 10 分間平均風速が $4 \mathrm{~m} / \mathrm{s}$ を超えるデータについてプロ ットしている。標準偏差はほぼ風速に比例した分布にな
っているといえるが，傾きの異なるデータが含まれてい るように見える。なお，図中の直線は，10\%，20\%，30\%の 乱流強度の傾きを表す。

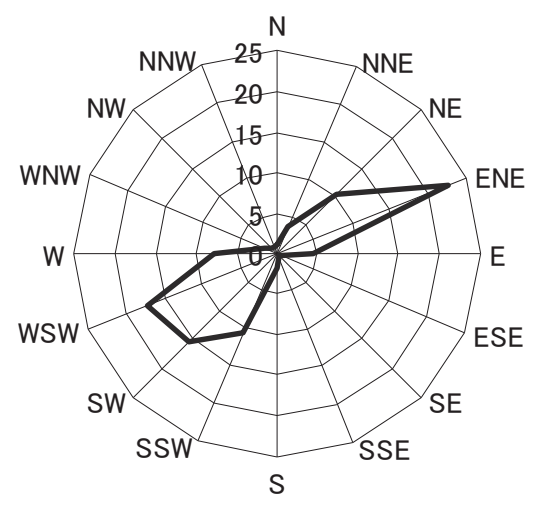

困 2 風配図（\%)

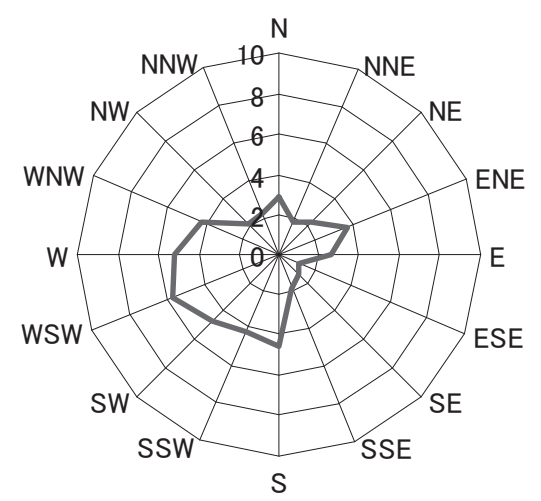

図 3 風向別平均風速 $(\mathrm{m} / \mathrm{s})$

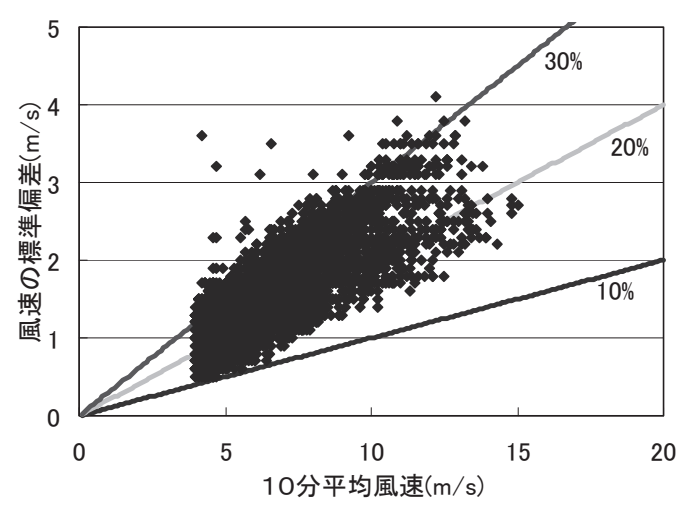

図4 平均風速と乱流強度の関係

乱流強度と風向の関係を図 5 に示す。発生頻度が風向 ごとに異なり，あまり発生していない風向もあるが，発 生頻度の高い風向で比較しても風向による乱流強度の違 いが顕著である。風向 $\mathrm{NE}, \mathrm{ENE}, \mathrm{E} （ 45 \sim 90^{\circ} ）$ の乱流強度 
は小さく 10～25\%程度である。風向 SSW, SW, W（202.5〜 $225^{\circ}, 270^{\circ}$ 付近）の乱流強度は大きく $30 \%$ 前後の值とな っている。風向WSW では, 乱流強度の大きい SW, W の間と なっているが, 乱流強度が小さくなっており，20\%程度と なっている。風上に農地が広がる北東側で小さく, 集落 が広がる南西側で大きくなっていると考えられる。この 地点の風の特徵として顕著なのは風向により乱流強度が 異なることである。ここから後の議論は, 乱流強度の小 さい風向のグループ (NE, ENE, E) と乱流強度の大きい風 向のグループ（SSW, SW, W) に分けて考察を進める。

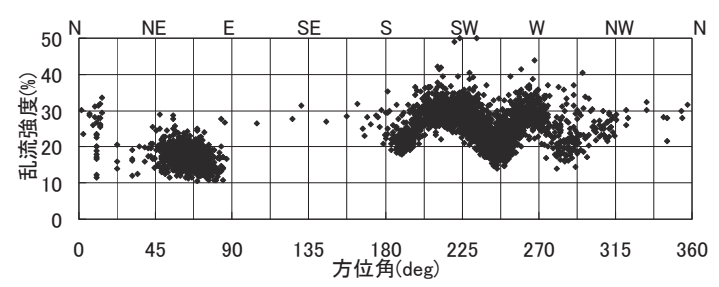

図 5 乱流強度と風向の関係

\section{2 平均風速が及ぼす影響}

図 6, 図 7 に 10 分間平均風速と室内で計測された風 の影響による等価音圧レベルの関係を, FLAT 特性および G特性について示す。なお, 図中のプロットは前章に示 した乱流強度により 2 つ風向群に分類している。

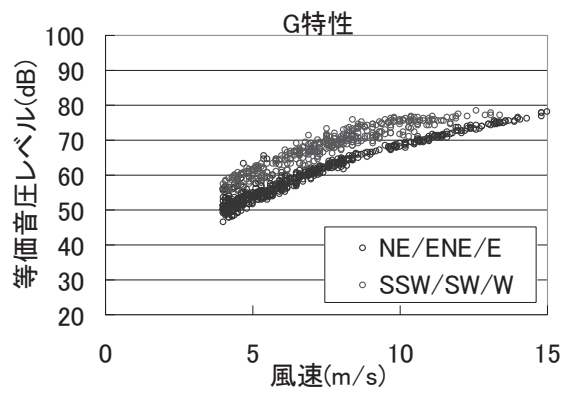

図6 平均風速と風の音圧レベルへの影響の関係 $(\mathrm{G})$

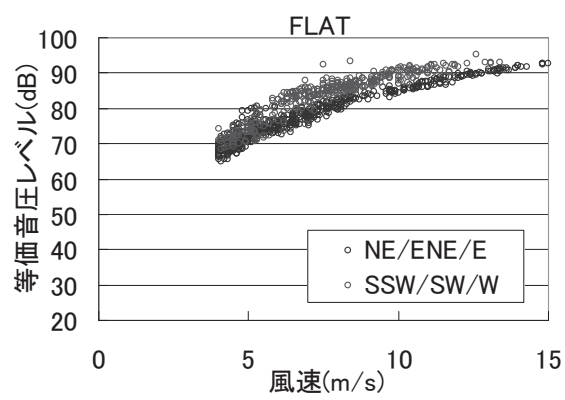

図 7 平均風速と風の音圧レベルへの影響の関係（F
風速の増加とともに風の影響が大きくなっている。 FLAT 特性では, 風速 $10 \mathrm{~m} / \mathrm{s}$ で $80 \mathrm{~dB}$ を超え, 風速 $15 \mathrm{~m} / \mathrm{s}$ では 90dB を超えている。また, 乱流強度の大きさにより 分類した $2 つ の$ 風向群で, 等価音圧レベルの大きさに差 が見られ，乱流強度が大きなものほど音圧一の風の影響 が大きく, G 特性においてその傾向が顕著である。

風速と風雑音の等価音圧レベルの関係を明確にするた め, 例として $10 \mathrm{~Hz}$ 帯域の $1 / 3$ オクターブバンドのプロッ トに対して近似曲線を引いたものを図8に示寸。なお, 低い風速の時にはデータがばらつくため, 10 分間平均風 速が $4 \mathrm{~m} / \mathrm{s}$ を超えるデータについて近似する。どちらのケ 一スにおいても，対数でよく近似できている。

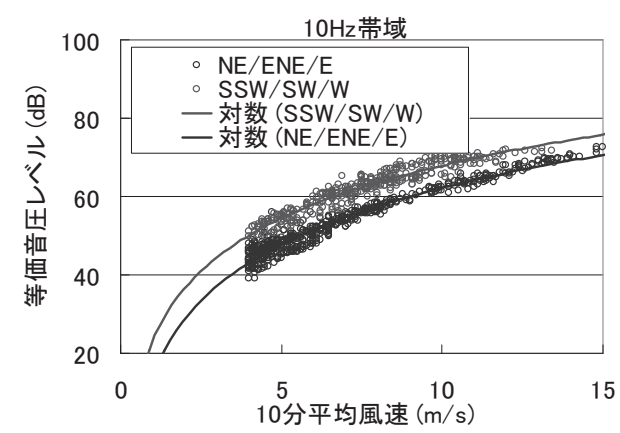

図 8 風速と音圧レベルの相関 $(10 \mathrm{~Hz}$ 帯域 $)$

風よる音圧 $\mathrm{P} は$ 風速の変動成分の影響を受けると考え ると, 式(1)のように変動成分の分散に比例するものと仮 定できる。

$$
\begin{aligned}
& P=C \times 1 / 2 \rho \sigma_{v}^{2}=C \times 1 / 2 \rho \times I_{v}^{2} \times v^{2} \\
& P: \text { 音圧 }(\mathrm{Pa}), v: \text { 平均風速 } \\
& C: \text { 係数, } \rho: \text { 空気密度 }\left(1.225 \mathrm{~kg} / \mathrm{m}^{3}\right) \\
& \sigma_{v}: \text { 変動風速の標準偏差, } I_{v}: \text { 乱流強度 }
\end{aligned}
$$

この音圧を音圧レベルの式に代入すると式(2)のように 展開できる。

$$
\begin{aligned}
& L_{p}=20 \log \left(\frac{P}{P_{0}}\right)=20 \log (P)-20 \log \left(P_{0}\right) \\
& =20 \log \left(C \times 1 / 2 \rho \times I_{v}^{2} \times v^{2}\right)-20 \log \left(P_{0}\right) \\
& =40 \log (v)+20 \log \left(I_{v}^{2}\right)+20 \log (C \times 1 / 2 \rho)-20 \log \left(P_{0}\right)
\end{aligned}
$$

式(2)の第 3 項, 第 4 項は定数項である。第 2 項は乱流 強度に関するものであり, 乱流強度が大きいほど音圧レ 
ベルが大きくなる。第 1 項は平均風速の 2 乗に関する項 で, 近似式の定数が 40 の值となる場合に音圧レベルが平 均風速の 2 乗に比例するという仮定が成立する。表 1 に 低周波音レベル計で計測されたすべての周波数帯域の結 果を式(3)の形で近似した場合の係数を示寸。ばらつきは あるが概水 Aの值は 40 に近い值となっており, どの周波 数帯域においても室内で発生する風の影響による音圧は 平均風速の 2 乗に比例するといえる。なお，風速の平均 成分 $\mathrm{v}$ と変動成分 $\mathrm{v}$ の足し合わせが風速波形だと考える と厳密には vv'の変動成分の項が卓越してくるが, この場 合にも定数Aが 40 であれば, 平均風速の 2 乗に比例する といえる。

$L_{p}(n)=A \log (V)+B$

表 1 対数近似曲線の係数

\begin{tabular}{|c|c|c|c|c|}
\hline 風向 & \multicolumn{2}{|c|}{$\mathrm{NE} / \mathrm{ENE} / \mathrm{E}$} & \multicolumn{2}{c|}{$\mathrm{S} / \mathrm{WSW} / \mathrm{WNW}$} \\
\hline 周波数 & $\mathrm{A}$ & $\mathrm{B}$ & $\mathrm{A}$ & $\mathrm{B}$ \\
\hline $1 \mathrm{~Hz}$ & 43.8 & 34.6 & 39.7 & 41.9 \\
\hline $1.25 \mathrm{~Hz}$ & 42.9 & 34.8 & 38.7 & 42.1 \\
\hline $1.6 \mathrm{~Hz}$ & 41.9 & 34.2 & 38.6 & 40.9 \\
\hline $2 \mathrm{~Hz}$ & 41.4 & 33.1 & 38.4 & 39.4 \\
\hline $2.5 \mathrm{~Hz}$ & 40.0 & 32.5 & 40.1 & 35.9 \\
\hline $3.15 \mathrm{~Hz}$ & 38.7 & 31.1 & 42.2 & 31.9 \\
\hline $4 \mathrm{~Hz}$ & 39.0 & 27.0 & 41.4 & 28.8 \\
\hline $5 \mathrm{~Hz}$ & 40.5 & 21.4 & 39.4 & 25.2 \\
\hline $6.3 \mathrm{~Hz}$ & 42.4 & 16.9 & 38.1 & 23.1 \\
\hline $8 \mathrm{~Hz}$ & 47.5 & 11.4 & 38.3 & 23.2 \\
\hline $10 \mathrm{~Hz}$ & 47.9 & 14.3 & 40.6 & 24.6 \\
\hline $12.5 \mathrm{~Hz}$ & 46.7 & 9.4 & 41.7 & 17.5 \\
\hline $16 \mathrm{~Hz}$ & 45.6 & 6.4 & 43.6 & 12.8 \\
\hline $20 \mathrm{~Hz}$ & 48.3 & 6.3 & 32.4 & 24.3 \\
\hline $25 \mathrm{~Hz}$ & 51.8 & -2.6 & 31.9 & 20.1 \\
\hline $31.5 \mathrm{~Hz}$ & 50.1 & -9.7 & 45.0 & 1.9 \\
\hline $40 \mathrm{~Hz}$ & 46.6 & -2.9 & 40.1 & 8.5 \\
\hline $50 \mathrm{~Hz}$ & 46.1 & -5.9 & 48.1 & -2.0 \\
\hline $63 \mathrm{~Hz}$ & 41.0 & -3.9 & 43.9 & -2.1 \\
\hline $80 \mathrm{~Hz}$ & 27.2 & 2.8 & 34.1 & 1.3 \\
\hline
\end{tabular}

\section{3 乱流強度が及ぼす影響}

乱流強度の影響については式(2)の第 2 項に関係するが, 第 2 項を展開すると $40 \log$ (I) と表記される。この項が足さ れたものが等価音圧レベルとなることから, 乱流強度が 大きければ大きいほど, 風の影響による音圧レベルは大 きくなる。

今回の計測では, 図 5 より乱流強度の小さい風向のグ ループ (NE, ENE, E) の乱流強度は 15〜20\%, 乱流強度の大 きい風向のグループ（SSW, SW, W）では概ね 30〜35\%程度 のとなっており, 両者の比は 1.5〜2 程度となる。1.5〜2 の值の $\log$ をとり 40 倍すると 7〜 $12 \mathrm{~dB}$ の差となるが, 図
5をみると概ねとの程度の差となっていることが確認で きる。よって, 乱流強度の影響により風による音圧レベ ルの増加が確認された。

\section{4 風が音圧に与える影響の周波数特性}

風が室内の音圧に与える影響の周波数特性を調べるた め，風によって発生する等価音圧レベルの周波数特性を 図 9 に示す。等価音圧レベルはレベル計からの1秒サン プリングのデータを 10 分間のパワー平均で算出している が，ここではこれらの 10 分のレベル值を前述の風向グル ープ，風速毎（間隔は $3 \mathrm{~m} / \mathrm{s}$ ピッチ）に計測期間中に得ら れた全データをアンサンブル平均したものを表示してい る。図中の直線は後述する周波数の $-5 / 3$ 乗で減衰する值 を音圧レベルにしたものである。
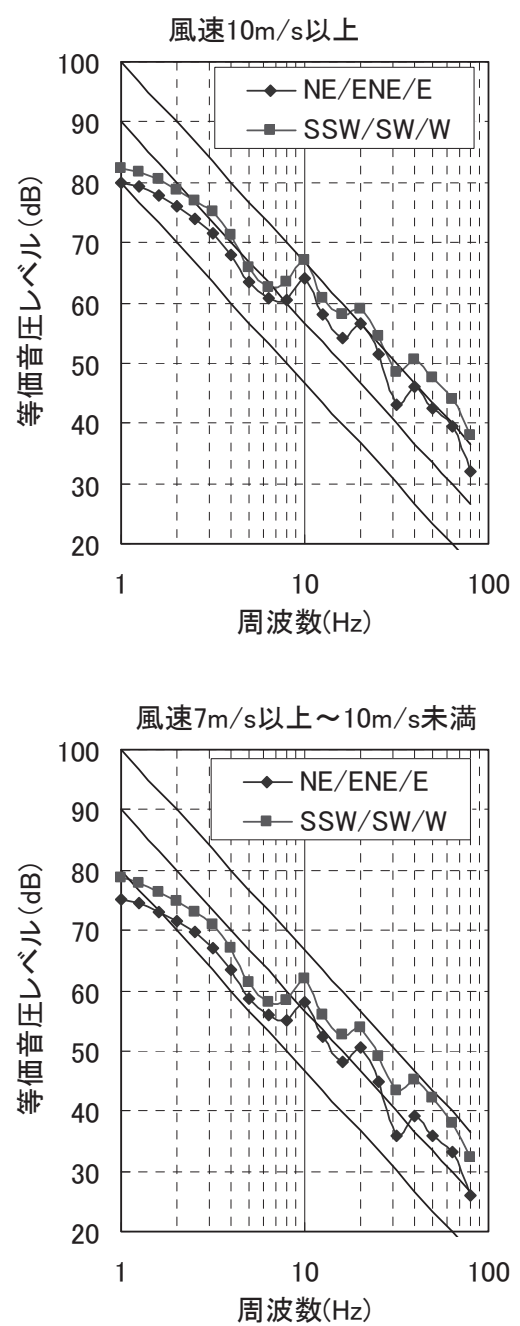


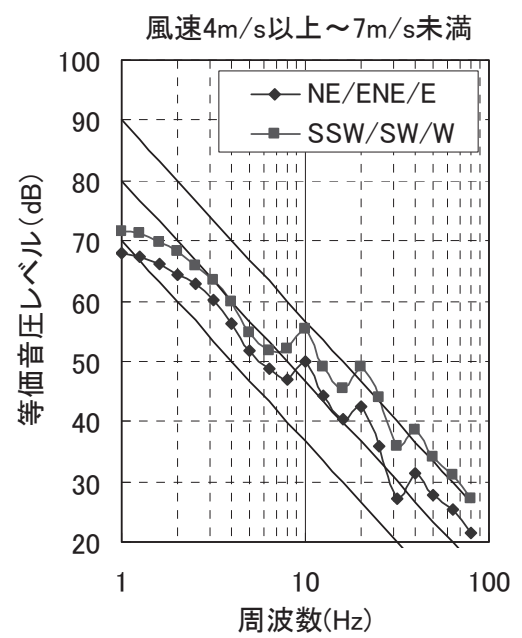

図9 風による音圧レベルへの影響の周波数特性

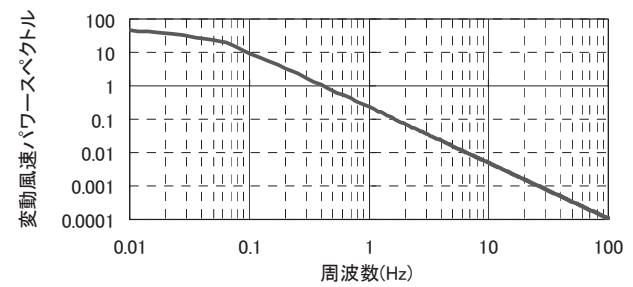

図 10 変動風速のパワースペクトル密度 2)

風による音圧の周波数特性としていえることは，周波 数とともに音圧が下がる傾向がある。このような周波数 特性をもつ音圧の測定結果が屋外測定等でよく見られる が，それは風の影響によるものではないかと考えられる。 この下がり方は, $5 \mathrm{~Hz}$ 以下の超低周波領域ではやや緩くな るが，その他の部分では図中に示した周波数の $-5 / 3$ 乗の 傾きと似た傾きで下がっていることが確認できる。変動 風速のパワースペクトル密度は一般にKarman型等に近似 される。図 10 は日本建築学会の建築物荷重指針 ${ }^{2)}$ に示 されている風速変動のパワースペクトルを今回の測定に 近い值を用いて実スケールで表したものである。音圧測 定で対象としている周波数領域はコルモゴロフの- $5 / 3$ 乗 則が成り立つ慣性小領域となっている。このことから， 周波数とともに音圧が下がる傾向は風の乱れの周波数分 布によるものと考えられる。

また, 図 9 において特定の周波数に見られる小さなピ 一クはどの風向風速の測定においてもみられることから， 計測を行った建物や測定室の形状や壁の材質等により透 過しや寸い周波数があるのではないかと考えられる。
$20 \mathrm{~Hz}$ にピークが見られるがこの波の波長は約 $17 \mathrm{~m}$ であり， この $1 / 4$ 波長が約 $4 \mathrm{~m}$ となり計測していた部屋の寸法に近 い值となっていることから，部屋の形状により定在波が 生じていたのではないかと考えられる。同様に考えると $10 \mathrm{~Hz}$ のピークは計測建物の大きさに起因するものではな いかと考えられる。

上記のような測定結果から, 風による音圧レベルは, 平均風速・乱流強度・乱れのパワースペクトルをパラメ ーターとして定式化が可能であると考えられる。ここで は, 式(1)に示したように変動圧は変動風速の 2 乗に比例 すると仮定して定式化を試みる。なお，風圧の変動は平 均風速 $\times$ 変動風速の項の影響の方が大きいが，今回の測 定結果では変動風速の 2 乗で整理した方が合いや寸そう であったためそれで展開する。

$p^{\prime}=c \times 1 / 2 \rho u^{\prime 2}$

$$
\begin{aligned}
P(n) & =C(n) \times 1 / 2 \rho \times S(n) \\
& =C(n) \times 1 / 2 \rho \times \hat{S}(n) \sigma_{u}^{2} / n \\
& =C(n) \times 1 / 2 \rho \times \hat{S}(n) / n \times I_{u}^{2} \bar{u}^{2}
\end{aligned}
$$

ここに,

$P(n)$ : 風の影響による音圧 $(\mathrm{Pa}) \quad p^{\prime}$ : 変動風圧 $(\mathrm{Pa})$ $\rho$ : 空気密度 $\left(1.225 \mathrm{~kg} / \mathrm{m}^{3}\right) \quad n$ : 周波数 $(\mathrm{Hz})$

$u^{\prime}:$ 変動風速 $(\mathrm{m} / \mathrm{s}) \quad \bar{u}:$ 平均風速 $(\mathrm{m} / \mathrm{s})$

$\sigma_{u}:$ 变動風速の標淮偏差 $(\mathrm{m} / \mathrm{s}) I_{u}$ : 乱流強度

$S(n)$ : 変動風速のパワースペクトル $c, C(n)$ : 係数 $\hat{S}(n)$ : 無次元パワースペクトル

風速変動のパワースペクトルを-5/3 乗則に従うと考え ると以下のように表される。

$$
\begin{aligned}
S(n) & =\hat{S}(n) \sigma_{u}^{2} / n=\hat{S}(n) / n \times I_{u}^{2} \bar{u}^{2} \\
& =a n^{-5 / 3} \times I_{u}^{2} \bar{u}^{2}
\end{aligned}
$$

パワースペクトルの形状を代入し, 対数を取って 20 倍 にすることで音圧レベル LP(n)にしたものが以下の式と なる。

$$
\begin{aligned}
L_{P}(n)= & 20 \log \left(P(n) / P_{0}\right) \\
= & 40 \log (\bar{u})+40 \log \left(I_{u}\right) \\
& +20 \log \left(D(n) \times a n^{-5 / 3}\right)+K \\
= & 40 \log (\bar{u})+40 \log \left(I_{u}\right)-100 / 3 \log (n) \\
& +20 \log (D(n))+K
\end{aligned}
$$


この式の最後の右辺第一項が平均風速に関する項であ

り，第 2 項は乱流強度に関寸るものである。第 3 項はパ ワースペクトルの形状によって決まってくる項であり風 の中ではカルマン型に近似される。第 4 項は計測してい る建物・部屋の寸法・形状によって決まってくる伝達関 数であり, 最後のKは定数項である。

このように室内音響計測時に騒音計等音響計測機器に 現れる風の影響は, 平均風速および乱流強度（変動風速 の標準偏差）を用いて定式化できることを示した。

4.おわりに

屋内において風が音圧に与える影響を長期計測した結 果から，周波数に関係なく室内で計測される音圧は風速 の 2 乗に比例することと, 周波数とともに音圧が下がる 現象は変動風速の成分により起こることを示した。

風の影響による音圧が平均風速の 2 乗に比例すること, 乱流強度によりレベルが上がること，周波数の-5/3 乗で 減衰することを組み合わせれば，風の影響を定式化する ことも可能だと考えられる。建物形状の影響等を伝達関 数として組み込んでいく方法および定式化は今後の課題 である。

参考文献

1）環境省，「低周波音の測定方法に関寸るマニュアル」， (2000)

2）日本建築学会編，「建築物荷重指針・同解説」,(2004) 